\title{
PROFESSIONAL DIGITAL COMPETENCE IN LANGUAGE EDUCATION
}

\author{
Elmira Tazhibayeva ${ }^{1}$, Natalya Mirza ${ }^{2}$ \\ ${ }^{1}$ E.A. Buketov Karaganda University, Karaganda, Kazakhstan \\ ${ }^{2}$ E.A. Buketov Karaganda University, Karaganda, Kazakhstan
}

ORCID ID $1: 0000-0002-5339-0343$

ORCID ID 2 : 0000-0001-8938-1812

\begin{abstract}
This article aims to unpack the term 'professional digital competence' and similar notions in language teacher education, to explore the existing Digital Competence Frameworks and their constituents. We also targeted to identify the most relevant findings in terms of digital competence of university language teachers through the analysis of scientific production in specialized literatures in the last decade (2012-2022). A search was carried out on Scopus database. After applying the inclusion and exclusion criteria, the sample was made up of 11 articles. The main findings helped to reveal the list of aspects investigated in terms of technology enhanced-foreign language teaching.
\end{abstract}

\section{INTRODUCTION}

The extensive use of digital technologies in all areas of human life requires new skills and competences [Arsova, 2021; Diachok et al, 2020; Goletiani et al, 2021; Nenkov et al, 2017; Valdmane et al, 2020]. A new era of competences includes new skills, but also lays new emphasis on old ones. Thus, equipping experts for new ways of thinking, ways of working, tools for working and living in the world as highlighted in Assessment and Teaching of Twenty First Century Skills framework [Scardamalia, M. et el., 2010]. It is traditionally assumed that 'digital competence' should be acquired in schooling systems, it has consequently resulted in a special interest in an educational research field around the globe [McGarr \& McDonagh, 2019]. Leading to another field of research development in the area of digital competence in education and more specifically in teacher training.

This interest is beneficial, for both developed economies with a long history of ICT use in education and developing countries. The review therefore targets to reveal the nature of 'professional digital competence' in language teacher education. In this regard, it is of paramount importance to unpack the term 'digital competence' and the terms associated with it. There exists considerable debate as to what extent does, and does not, entail, since it is a novel and an evolving concept [Ilomaki et al., 2016]. It is also important to distinguish the features of each similar phrases used to describe technology-related competences and explore the various models and their constituents.

\section{THE MAIN PART}

The capacity to use technology effectively is known as an integral competency under European framework. Meanwhile many different concepts are used to describe these skills and competencies, such as; ICT competence, IT competence, digital literacies, digital fluency, digital skills, e-competencies, e-skills, and twenty first century skills and competencies. European Commission [REC, 2006] states that digital competence is in the list of key competences for lifelong learning. Four years afterwards, the significance of the recommendation is recognized in the 2020 Strategy [European commission, 2010]:

«Digital competence» comprises the confident and critical use of Information Society Technology (IST) for work, for leisure and communication. It is underpinned by basic skills in IT: the use of computers to retrieve, assess, store, produce, present and exchange information, and to communicate and participate in collaborative networks via the Internet [REC, p.7].

To be digitally competent, one needs to understand the functions of main computer applications, online and internet communication's risks, the role of online tools in supporting 
innovation and creativity, the validity and reliability of online information, the legal and ethical principles within collaborative online-activities. Meanwhile, being digitally literate implies the ability to understand a media, to search and being critical about retrievable information and to be able to communicate with other people through a variety of digital tools and applications.

Regarding professional digital competence in teacher education is defined from two perspectives. Firstly, the ability to demonstrate the use technology skillfully encouraging students to do the same. Secondly, routinely using pedagogical methods that focus on ICT enhancing the students learning experience [Krumsvik, 2012] .

In National professional standard for educators, ICT competence is still in use and it is distinguished by two levels: basic and pedagogical ICT skills [PS, 2017].

In DigCompEdu model, pedagogical digital competence has been defined as as 'a set of skills, abilities and attitudes that the teacher must develop to incorporate digital technologies into their practice [DigCompEdu, 2017]. Others assume that this refers to the 'embodiment of technological and didactic excellence' [EC, 2010]. Thus, teachers are required to implement a successful integration and use of ICT with an adequate level of pedagogical digital competence.

The Professional Digital Competence framework for teachers, designed by Norwegian scholars in 2017, based on the development of seven specific points with a set of knowledge, skills and competence [Kelentrić et al., 2017]. Similarly, in pedagogical digital fluency framework designed by Russian scholars, where digital fluency regarded as a synonymous notion to digital competence, presented as a 'triple power' of three units such as personally-motivated, theoretically-scientific and practically-active [Starichenko, 2015]. Both guidance documents highlight the primary role of teachers in shaping school students' digital skills. All the constituents are equally important but it is the sum of competence areas that makes up a professionally digitally competent teacher [EU, p.16].

Fernández -Batanero, J.M and el. also have noted to the lack of sources on the challenges imposed by technology integration at the tertiary level. Some strategic programs in use of technologies among university in-service and pre-service teachers have been designed and implemented [Fernández-Batanero et al., 2021]. One of the main factors effecting on the success of the programs concerns to the behavior of users. It is generally evaluated by the subjective means, such personal traits and behavioral intention [Ajibade, 2018] .

When it comes to professional digital competence of language educators, Sysoyev and Evstigneyev state that 'competency in integrarting technology in language learning is a constituent of a foreign language teacher's professional competency' [Sysoyev \& Evstigneyev, 2016].

Sartor believes that foreign language teachers' professional competency strongly requires creating a positive presence by means of:

- introduction videos;

- personalizing virtual background;

- teacher's voice is as a key tool: pitch-tone-volume;

- focus on what students say when they are off the topic;

- focus in the screen background;

- use of one platform on a professional level;

- use of computer presentation tools;

- alignment of outside tools with lesson objectives [Sartor, 2020].

Meanwhile, in a methodological guide 'Small teaching online' by Flower Darby and James M. Lang it is highlighted the importance of backward design method in digital language practice [Darby \& Lang, 2019]. The backward approach to teaching, the shift from conventional habits to goalscentered tasks analysis. It recalls us to begin with a question: What kind of lessons and practices are needed to master key performances? The process of thinking like an assessor result in students' better performance since they are clear with learning goals. The logic of backwards design is based on the sequence of 3 stages completion.

Stage 1: Identifying desired results

Stage 2: Determine acceptable evidence

Stage 3: Plan learning experiences and instruction. 
When it comes digital learners' s successful engagement, it depends on the digital language teacher's ability to breakdown complex tasks into small units and build an online community for a regular support and feedback. Monitoring questions on the online forums and chat rooms, personalized e-mailing, virtual office hours benefit greatly in boosting students' learning motivation.

For another source of relevant studies, Scopus database was applied using the key words 'digital competence' and 'higher education', with no restriction to language in the period from 2012 to 2022. The choice of database was based on the three main grounds: firstly, abstract and citation database of peer-reviewed scientific content; secondly, a global and regional coverage of scientific journals, conference proceedings and books; thirdly, distribution of publishers. Similarly, university teachers were selected as the subject for the research since the issue of training university educators in relation to digital technologies still requires a careful study.

The search conducted in October, 2021. The total results showed 901 publications. 17 works were excluded from the data, since have not been published yet. The selection process was aimed to answer the following questions: level?

What scientific fields provide the most findings relating to digital competence at the tertiary period?

What country has the greatest number of publications on the research topic in the selected

What scholar can be acknowledged as an expert in revealing the issues on digitalization in Social Sciences (based on the published works meeting quality and quantity criteria during the selected period)? university level?

How many works (case studies) are based on the analysis of digitalization process at

\section{RESULTS}

The analysis has drawn on a wide range of sources, however a significant number of these are from Social Sciences (32,1\%) and Computer Sciences (20,9\%). From the regional differences, a high level of attention is shared among Spain, Russia and the USA in comparison to other countries (see Figure 1). In the given period, Julio K. Almenara coauthoring with other experts published 96 works, dedicated to the following aspects of Digitalization: Technology Acceptance Model, Augmented Reality, Authoring Tools, Online Learning, Internet Use, Addiction and Gaming.

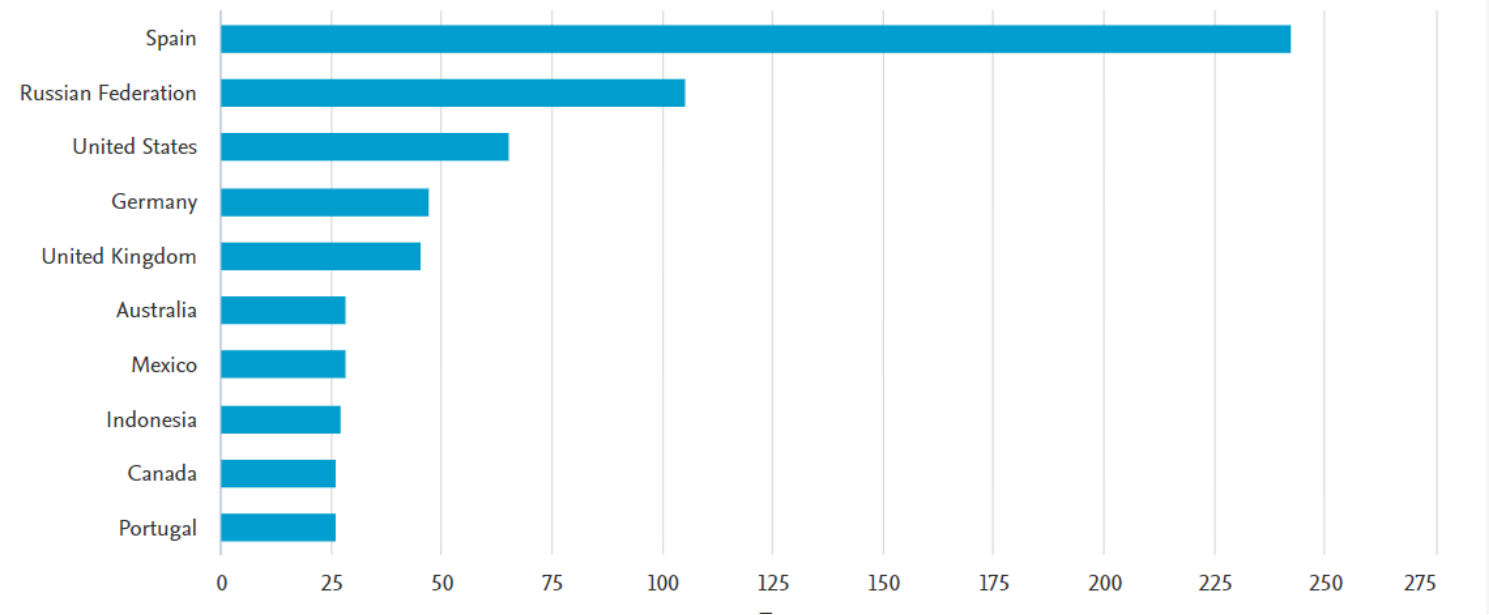

Fig. 1. Total percentages of the cited countries and research papers on Digital Competence

After implying inclusion and exclusion criteria the sample was made up of 11 articles dedicated to the practices among foreign language teachers in the context of transitioning from traditional classroom to online higher education. Specifically covering the following aspects of technology and language integration: 
- A technology and language program development;

- E-portfolio as a means of building commumicative competence of future teachers;

- Benefits of digital language classroom for learners' autonomy;

- E-skills and soft skills in developing interdisciplinary professional awareness of Foreign Languages students;

- Augmented Reality in foreign language teaching;

- Didactic Potentials of MOOCs

- Digital language tools.

The sample's results have revealed insufficiency of quality works in a regional and global scope. Thus, the table below summarizes the main findings selected from Scopus base (see Table 1.)

Table 1. Summary of main findings

\begin{tabular}{|c|c|c|}
\hline № & Articles & Main input \\
\hline 1 & $\begin{array}{l}\text { The use of modern technologies } \\
\text { by foreign language teachers: Developing } \\
\text { digital skills (Biletska et al., 2021) }\end{array}$ & $\begin{array}{l}\text { A technology and language integration program } \\
\text { development for pre-service language } \\
\text { educators }\end{array}$ \\
\hline 2 & $\begin{array}{l}\text { Using the electronic portfolio as a means of } \\
\text { formation the foreign language } \\
\text { communicative competence when training } \\
\text { future tutors-teachers (Babushkina et al., } \\
2021 \text { ) }\end{array}$ & $\begin{array}{l}\text { - Tilda tools for future tutors-teachers in } \\
\text { designing E-portfolio as a means of shaping } \\
\text { foreign language communicative competence }\end{array}$ \\
\hline 3 & $\begin{array}{l}\text { The role of digitalization in the process of } \\
\text { teaching a foreign language and in the } \\
\text { formation of a foreign language } \\
\text { competence of future specialists (Saraeva, } \\
\text { 2021) }\end{array}$ & $\begin{array}{l}\text { Technologies in a foreign language teaching as } \\
\text { a booster of self-learning skills and linguistic } \\
\text { competence of student-teachers. }\end{array}$ \\
\hline 4 & $\begin{array}{l}\text { E-skills and digital literacy for foreign } \\
\text { languages education: Student case study in } \\
\text { Ukraine (Makhachashvili \& Semenist, } \\
\text { 2021) }\end{array}$ & $\begin{array}{l}\text { The empirical case of digital skills viral } \\
\text { development and application to construe } \\
\text { interdisciplinary competencies of students of } \\
\text { European and Oriental Languages major } \\
\text { programs in Ukraine. }\end{array}$ \\
\hline 5 & $\begin{array}{l}\text { Features of using methods and means of the } \\
\text { augmented reality technology when } \\
\text { teaching a foreign language (Sergeeva et al., } \\
\text { 2021) }\end{array}$ & $\begin{array}{l}\text { AR tools (Google Lens, augmented reality } \\
\text { browsers, WallaMe service) mastered as a part } \\
\text { of the course "Virtual and Augmented Reality } \\
\text { Technologies" } \quad \text { Stepik platform } \\
\text { (https://stepik.org/course/62107/syllabus). }\end{array}$ \\
\hline 6 & $\begin{array}{l}\text { Digital educational environment as a factor } \\
\text { of foreign language competences } \\
\text { development (Rybakova, 2021) }\end{array}$ & $\begin{array}{l}\text { Comparison of application efficiency in using } \\
\text { traditional and digital techniques for } \\
\text { forming foreign language competences at } \\
\text { MIREA - Russian Technological University. }\end{array}$ \\
\hline 7 & $\begin{array}{l}\text { Digital transformation of the educational } \\
\text { university space while teaching foreign } \\
\text { languages (Gridasova et al., 2020) }\end{array}$ & $\begin{array}{l}\text { A safe digital educational environment aims to } \\
\text { provide high quality language education. }\end{array}$ \\
\hline 8 & $\begin{array}{l}\text { A comparative study of Spanish adult } \\
\text { students' attitudes to ICT in classroom, } \\
\text { blended and distance language learning } \\
\text { modes (Arrosogaray et al., 2019) }\end{array}$ & $\begin{array}{l}\text { Adult students' attitudes towards ICT in three } \\
\text { different formal learning settings: classroom } \\
\text { face-to-face, blended and distance language } \\
\text { learning modes. }\end{array}$ \\
\hline 9 & 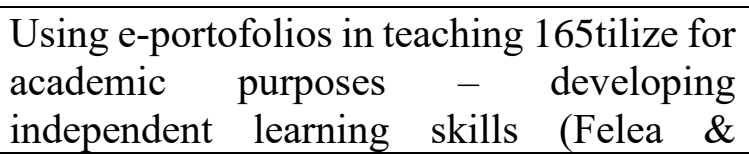 & E-portfolio as a collection of digital artefacts. \\
\hline
\end{tabular}




\begin{tabular}{|l|l|l|}
\hline & Ctanca, 2019) & \\
\hline 1 & $\begin{array}{l}\text { What the good (digital) language learner } \\
\text { can teach us? (Turula, 2016) }\end{array}$ & $\begin{array}{l}\text { Good language learners (with reference to good } \\
\text { learner studies of the 1970s) effectively } \\
\text { 166tilize the "plethora of creative routes for } \\
\text { digital language learning". }\end{array}$ \\
\hline 1 & $\begin{array}{l}\text { Language tools: Communicating in today's } \\
\text { world of business (Ribeiro et al., 2015) }\end{array}$ & $\begin{array}{l}\text { Insights on how technology, namely Machine } \\
\text { Translation and Computer-Aided Translation, } \\
\text { is perceived by business communicators who } \\
\text { are learning English in an ESP environment. }\end{array}$ \\
\hline
\end{tabular}

\section{CONCLUSION}

Technology enhanced learning has become an objective of universities in various countries around the globe. Due to the fact that digital tools can improve the teaching and learning processes of students. The perception of university teachers regarding the use of digital technologies in the language classroom turns to be somewhat positive, since it is regarded as one of the key competences in professional frameworks of teachers.

Thus, the digital competence of language teachers correlates with professional ICT competence in a digital environment with a profound ICT knowledge and high proficiency in integrating technologies into a language classroom. The language teachers have been exposed to the use of digital devices due to the global pandemic situation. The technology integrated language classroom has drastically changed nature of the teacher's instruction and students' learning pace and its gradual implementation can guarantee favorable outcomes.

\section{REFERENCES}

Ajibade, P. (2018). Technology Acceptance Model Limitations and Criticisms: Exploring the Practical Applications and Use in Technology-related Studies, Mixed-method, and Qualitative Researches. Library Philosophy and Practice (e-journal). 1941. from http://digitalcommons.unl.edu/libphilprac/1941

Arsova, D. (2021). Skills and competencies of the new generation of students to work with digital devices // "Innovations in technology and education": proceedings of XIV International scientific conference "Innovations in technology and education", 26 march 2021 г.: Kuzbass State Technical University, Belovo, Russia; 2021. - vol. 3., pp. 59-66 (in BG)

Darby, F. \& Lang, J. M. (2016). Small teaching: Everyday lessons from the science of learning. San Francisco, CA: JosseyBass. 419-422p.

Diachok, N., Chernukha, N., Tokaruk, L., Udovenko, I., Petrova, M. (2020). Practical-oriented concept as a principle of professional education of the future professionals. International Journal of Higher Education, Vol. 9, No. 4, August 2020, pp.272-282, https://doi.org/10.5430/ijhe.v9n4p272

European Commission (2010). Europe 2020 - European strategy for smart, sustainable and inclusive growth. COM (2010) 2020 Annex 2. Bruxelles: European Commission. 3 March 2010

EC (European Commission). (2017). Digital competence framework for educators (DigCompEdu). Accessed November 16, 2019: https://ec.europa.eu/jrc/en/digcompedu

European Council (2006). Recommendation of the European Parliament and the Council of 18 December. 2006 on Key Competencies for Lifelong Learning. Bruss. Off. J. Eur. Un. 2006, 30

European Commission (2010). Commission Communication "Europe 2020 - A strategy for smart, sustainable and inclusive growth". https://ec.europa.eu/eu2020/pdf/COMPLET\%20EN\%20BARROSO\%20\%20\%20007\%20\%20Europe\%202020\%20-\%20EN\%20version.pdf 
Fernández-Batanero, J.M., Román-Graván, P., Montenegro Rueda, M., López-Meneses, E. \& Fernández-Cerero, J. (2021) Digital Teaching Competence in Higher Education: A Systematic Review. Sci. 2021, 11, 689. https://doi.org/10.3390/ educsci11110689

Goletiani, K., Mushkudiani, Z., Gulua, E., Janelidze, N. (2021). Difficulties in managing diversity in Georgian educational organizations. Access to science, business, innovation in digital economy, ACCESS Press, 2(2): 123-137. https://doi.org/10.46656/access.2021.2.2(1)

Ilomaki, L., Paavola, S., Lakkala, M., \& Kantosalo, A. (2016). Digital competence-an emergent boundary concept for policy and educational research. Education and Information Technologies, 21(3), 655-679p.

Kelentrić M., Helland K. \& Arstorp A.T. (2017) Professional Digital Competence Framework for Teachers. The Norwegian Centre for ICT in Education, P.75

Krumsvik, R. A. (2012). Teacher educators' digital competence. Scandinavian Journal of Educational Research, 1-12p.

McGarr, O. \& McDonagh, A. (2019) Digital Competence in Teacher Education, Output 1 of the Erasmus + funded Developing Student Teachers' Digital Competence (DICTE) project. https://dicte.oslomet.no/

Nenkov, N., Dyachenko, Yu., Petrova, M., Bondarenko, G., Pustovit, V. (2017). Intelligent and Cognitive Technologies in Education of International Economic Relations Students and Human Resource Development in Enterprises: Methodology in Language. European Journal of Sustainable Development, http://www.ecsdev.org/, Rome, Italy, Vol 6, No.4, 2017, pp.353-360, https://doi.org/10.14207/ejsd.2017.v6n4p353

Professional'nyj standart «Pedagog» (2017). [Professional Standart «Teacher»] Prilozhenie k prikazu Predsedatelja Pravlenija Nacional'noj palaty predprinimatelej Respubliki Kazahstan

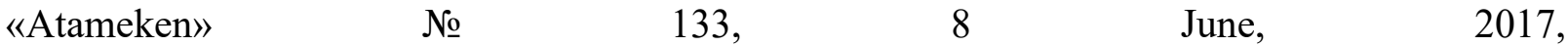
https://atameken.kz/uploads/content/files/ПС\%20Педагог.pdf [in Russian]

Sartor, V. (2020). Personalizing your online learning https://eflmagazine.com/personalising-youronline-teaching/

Scardamalia, M., Bransford, J., Kozma, B., \& Quellmalz E. (2010). Assessment and Teaching of 21 Century Skills (2010). Cisco. https://www.cisco.com/c/dam/en_us/about/citizenship /socioeconomic/docs/ATC21S Exec Sum

Starichenko, B.E. «Professional'nyj standart i IKT-kompetencii pedagoga» [Professional Standart of educator’s ICT competence]// Pedagogicheskoe Obrazovanie V Rossii, 2015, № 7, 6-15p. [in Russian]

Sysoyev P.V. \& Evstigneyev M.N. (2011). Kompetencija uchitelja inostrannogo jazyka v oblasti ispol'zovanija informacionno-kommunikacionnyh tehnologij: opredelenie ponjatij i komponentnyj sostav [Competence of a foreign language teacher in the use of information and communication technologies: definition of concepts and components] // Inostr. jazyki v shkole. 2011. № 6. 16-20p. [in Russian]

Valdmane, L., Zariņa, S., Iliško, D., Badjanova, J., Petrova, M. (2020). Empowering of digital and media literacy of primary school teachers in Latvia. EDULEARN20, 12th annual International Conference on Education and New Learning Technologies, 6th - 7th of July, 2020, https://iated.org/edulearn/; Proceedings of EDULEARN20 Conference 6th-7th July 2020, ISSN: 2340-1117, pp.4022-4029, DOI: 10.21125/edulearn.2020.1087 